in our experimental sows, whereas the behaviour of the sows after weaning at $2 \mathbf{I}$ days was similar to that of the controls.

The number of piglets born after early weaning in the sows varied a slight decrease of prolificacy (0.5-0.6 piglets/litter at birth) as a result of weaning at Io days.

Moreover, in our rearing conditions, mortality of the piglets was similar for all groups. Weight gains of the piglets to 8 weeks were almost the same but were a little lower, in the case of those weaned at Io days ( $15.2 \mathrm{~kg}$ for $\mathrm{S}_{10} ; 17.0 \mathrm{~kg}$ for $\mathrm{S}_{21} ; 16.5 \mathrm{~kg}$ for $\mathrm{S}_{35}$ ).

From the observations made during this trial, it may be concluded that productivity of the sow can be increased by weaning the litter early. However, successful application of these methods in practice depends on the technical ability of the producer, and further research is needed to increase the knowledge of this field and to apply these techniques in practice.

\title{
ÉTUde DES PERTES DE POIDS SUBLEs PAR DES PORCELETS AU COURS DE TRANSPORTS SUR ROUTE
}

\author{
R. DANTZER \\ Laboratoire de Pharmacologie-Toxicologie, I. N.R. A., \\ 180, Chemin de Tournefeuille, \\ 31 - Toulouse-Saint-Martin-du-Touch
}

\section{RÉSUMÉ}

Les pertes de poids insensibles subies par des porcelets âgés de 2 mois à 3 mois et demi, au cours d'un transport sur route, augmentent avec le poids des animaux, la durée du transport et la température extérieure. Elles sont égales en moyenne à 1,20 p. Ioo du poids initial, pour une durée de deux heures. La signification et la nature de ces pertes de poids sont discutées.

\section{SUMMARY}

\section{A STUDY OF THE LOSSES SUSTAINED BY YOUNG PIGS DURING TRANSIT}

The loss of weight seen during a two hours journey by road is equivalent to a reduction of the initial weight by $1.20 \mathrm{p}$. I0o. These losses increase with the length of the journey and the weight of animals. They are even greater when the outside temperature is high :

$$
\left(\mathrm{F} \frac{\mathrm{I}}{\mathrm{I} 5}=\mathrm{I} 6.45 ; \mathrm{P}=0.025\right)
$$

:and the relative humidity is lower $\left(\mathrm{F} \frac{\mathrm{I}}{\mathrm{I} 5}=8.7 \mathrm{I} ; \mathrm{P}=0.0 \mathrm{I}\right)$ The weight changes cannot be .explained wholly by handling of animals or incarceration since pigs kept in a stationary lorry ilost only $0.77 \mathrm{p}$. Ioo of the initial weight after two hours. 
Comparison of these results with physiological weight loss over an equivalent time period suggests that the loss of weight is because of increase in evaporation from skin and respiratory tract ; however the metabolic variations which may occur with transport have not yet been determined.

The loss of weight could be used as a test to search for appropriate drugs during transit. 